\title{
Dynamics and control analysis of a single flexible link robot with translational joints
}

\author{
Bien Duong Xuan*

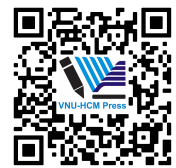 \\ Use your smartphone to scan this \\ QR code and download this article
}

Le Quy Don Technical University, $\mathrm{Ha}$ Noi, Vietnam

\section{Correspondence}

Bien Duong Xuan, Le Quy Don Technical University, Ha Noi, Vietnam

Email: duongxuanbien@lqdtu.edu.vn

History

- Received: 14-4-2020

- Accepted: 22-12-2020

- Published: 31-12-2020

DOI : 10.32508/stdjet.v3i4.801

\section{Check for updates}

Copyright

(c) VNU-HCM Press. This is an openaccess article distributed under the terms of the Creative Commons Attribution 4.0 International license.

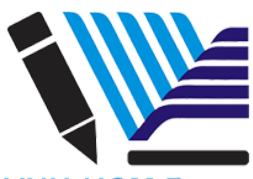

VNU-HCM Press

\begin{abstract}
Modern design always aims at reducing mass, simplifying the structure, and reducing the energy consumption of the system especially in robotics. These targets could lead to lowing cost of the material and increasing the operating capacity. The priority direction in robot design is optimal structures with longer lengths of the links, smaller and thinner links, more economical still warranting ability to work. However, all of these structures such as flexible robots are reducing rigidity and motion accuracy because of the effect of elastic deformations. Therefore, taking the effects of elastic factor into consideration is absolutely necessary for kinematic, dynamic modeling, analyzing, and controlling flexible robots. Because of the complexity of modeling and controlling flexible robots, the single-link and two-link flexible robots with only rotational joints are mainly mentioned and studied by most researchers. It is easy to realize that combining the different types of joints of flexible robots can extend their applications, flexibility, and types of structure. However, the models consisting of rotational and translational joints will make the kinematic, dynamic modeling, and control becomes more complex than models that have only rotational joints. This study focuses on the dynamics model and optimal controller based on genetic algorithms (GA) for a single flexible link robot (FLR) with a rigid translational joint. The motion equations of the FLR are built based on the Finite Element Method (FEM) and Lagrange Equations (LE). The difference between flexible manipulators that have only rotational joints and others with the translational joint is presented through boundary conditions. A PID controller is designed with parameters that are optimized by the GA algorithm. The cost function is established based on errors signal of translational joint, elastic displacements of the End-Point (EP) of the FLR. Simulation results show that the errors of the joint variable, the elastic displacements (ED) are destructed in a short time when the system is controlled following the reference point. The results of this study can be basic to research other flexible robots with more joint or combine joint styles.
\end{abstract}

Key words: flexible link robot, translational joint, elastic displacements, control, genetic algorithm

\section{INTRODUCTION}

Dynamics and control are fundamental problems in the robotics field. The modeling and building of the motion equations problems meet challenges with the robot which has many degrees of freedom. Especially the robots take into account the ED factor of links. There are many studies on the FLR. However, the robot model mentioned in such works has only rotational joints ( $\mathrm{R}$ joint). The translational joint $(\mathrm{T}$ joint) has almost not been considered yet. The inclusion of the $\mathrm{T}$ joint into the FLR increases flexibility, further enriching the application of this robot type. Of course, the modeling complexity also increases. Few authors have studied the FLR with only $\mathrm{T}$ joint. A single FLR with $\mathrm{T}$ joint is presented in Wang and Wei (1987) ${ }^{1}$. The Galerkin method is used to model the robot. The authors also proposed a feedback control law in Wang and Wei (1987) ${ }^{2}$. Kwon and Book ${ }^{3}$ present a single link robot which is described and modeled by using assumed modes method (AMM). Stable inversion method is studied for the same robot configuration but the nonlinear effect is taken into account ${ }^{4}$. A new method to solve the inverse dynamics of a FLR is described in ${ }^{5}$.

Some FLR with a T joint combining a $\mathrm{R}$ joint are considered in Pan et al. (1990) ${ }^{6}$, Yuh and Young $(1994)^{7}$, Bedoor and Khulief (1997) ${ }^{8}$. The main approach was based on the Assumed mode method (AMM) and a few works were based on FEM to model the system. A FLR with $\mathrm{R}$ and $\mathrm{T}$ joints was presented in Pan et al. (1990) ${ }^{6}$ based the FEM approach. The Newmark method was used to solve the motion equations of the robot. The Partial Differential Equations was established in Yuh and Young $(1994)^{7}$ for a FLR with R-T joint by using AMM. A general dynamic model for RT robot was introduced in Bedoor and Khulief (1997) [8] based on FEM and LE approach.

A Fuzzy Logic controller was designed in Farid and Salimi $(2001)^{9}$ to track the motion of a FLR with R- 
$\mathrm{T}$ joint. An adaptive control of a single FLR with $\mathrm{T}$ joint with the ball-screw mechanism was studied in Qiu (2012) ${ }^{10}$. This controller is also mentioned in Zhao and $\mathrm{Hu}(2015)^{11}$ with AMM and LE approach. In this study, the dynamics model and optimal controller of a single FLR with a $\mathrm{T}$ joint are considered based on the FEM and LE approach. The T joint variable is defined which is distance from element at the origin coordinate system to the EP of link. The value of depends on time. The position of other elements is changed too. Number of elements can be optionally selected and enough huge. A PID controller is designed with parameters which are optimized by using GA algorithm. Cost function is built based on errors signal of $\mathrm{T}$ joint variable, ED of the EP of the FLR.

\section{MATERIALS AND METHODS}

The structure of a single FLR with T joint is considered in Figure 1.

The XOY is the fixed frame. A flexible link is divided into $n$ elements. Each element has 2 nodes. Each node $j$ has the flexural $\left(u_{2 j-1}, u_{2 j+1}\right)$ and the slope displacements $\left(u_{2 j}, u_{2 j+2}\right)$. The length of an element is $l_{e}=\frac{L}{n}$ with is the total length of flexible link. The T joint variable is $d(t)$ which is changed by driven force $F_{T}(t)$. The $F_{y}$ is external force at the EP of the link. Element $k$ is inside the hub of the T joint

$$
k . l e=L-d(t)
$$

It is noteworthy to mention that value of $k$ is the number of position element. So, it must be taken the raw value of $k$ in computing process. Total elastic displacement $w_{j}\left(x_{j}, t\right)=N_{j}\left(x_{j}\right) Q_{j}(t)$ with $0 \leq$ $x_{j} \leq l_{e}$ and generalized vector of shape functions $N_{j}\left(x_{j}\right)=\left[x_{j} f_{1}\left(x_{j}\right) f_{2}\left(x_{j}\right) f_{3}\left(x_{j}\right) f_{4}\left(x_{j}\right)\right]$ of element $j$ are presented with generalized elastic displacement $Q_{j}(t)=\left[\begin{array}{lllll}d(t) & u_{2 j-1} & u_{2 j} & u_{2 j+1} & u_{2 j+2}\end{array}\right]^{T}$ vector. Coordinate $r_{j}$ of element $j$ is given by

$$
r_{j}=\left[(j-1) l_{e}-L+d(t)+x_{j} w_{j}\left(x_{j} t\right)\right]^{T}
$$

Elastic kinetic energy (KE) of element $j$ is determined as

$$
\begin{aligned}
T_{j} & =\frac{1}{2} \int_{0}^{l_{e}} m\left[\frac{\partial r_{j}}{\partial t}\right]^{2} d x_{j} \\
& =\frac{1}{2} Q_{j}^{T}(t) M_{j} Q_{j}(t)
\end{aligned}
$$

Where $m$ is mass per meter. Mass matrix $M_{j}$ of element $j$ is calculated as

$$
\begin{gathered}
M_{j}(s, e)=\int_{0}^{l_{e}} m\left[\frac{\partial r_{j}}{\partial Q_{j s}}\right]^{T}\left[\frac{\partial r_{j}}{\partial Q_{j e}}\right] d x_{j} ; \\
s, e=1,2 \ldots, 5
\end{gathered}
$$

Where $Q_{j s}$ and $Q_{j e}$ are the $s^{t h}, e^{t h}$ element of $Q_{j}$ vector. It can be shown that $M_{j}$ is of the form

$$
\begin{aligned}
& M= \\
& {\left[\begin{array}{ccccc}
m l_{e} & 0 & 0 & 0 & 0 \\
0 & \frac{13}{35} m l_{e} & \frac{11}{210} m l_{e}^{2} & \frac{9}{70} m l_{e} & -\frac{13}{420} m l_{e}^{2} \\
0 & \frac{11}{210} m l_{e}^{2} & \frac{1}{105} m l_{e}^{3} & \frac{13}{420} m l_{e}^{2} & -\frac{1}{140} m l_{e}^{3} \\
0 & \frac{9}{70} m l_{e} & \frac{13}{420} m l_{e}^{2} & \frac{13}{35} m l_{e} & -\frac{11}{210} m l_{e}^{2} \\
0 & -\frac{13}{420} m l_{e}^{2} & -\frac{1}{140} m l_{e}^{3} & -\frac{11}{210} m l_{e}^{2} & \frac{1}{105} m l_{e}^{3}
\end{array}\right]}
\end{aligned}
$$

The potential energy (PE) of element $j$ includes two components: elastic $\mathrm{P}_{j}$ and gravity $\mathrm{G}_{j}$ potential energy.

$$
\begin{aligned}
P_{j} & =\frac{1}{2} \int_{0}^{l_{j}} E I\left[\frac{\partial^{2} w_{j}\left(x_{j}, t\right)}{\partial x_{j}^{2}}\right]^{2} d x_{j} \\
& =\frac{1}{2} Q_{j}^{T}(t) K_{j} Q_{j}(t)
\end{aligned}
$$

Where, $E$ and $I$ are Young's modulus and inertial moment of link. The stiffness matrix $K_{j}$ is shown as

$$
K_{j}=\frac{E I}{l_{e}^{3}}\left[\begin{array}{ccccc}
0 & 0 & 0 & 0 & 0 \\
0 & 12 & 6 l_{e} & -12 & 6 l_{e} \\
0 & 6 l_{e} & 4 l_{e}^{2} & -6 l_{e} & 2 l_{e}^{2} \\
0 & -12 & -6 l_{e} & 12 & -6 l_{e} \\
0 & 6 l_{e} & 2 l_{e}^{2} & -6 l_{e} & 4 l_{e}^{2}
\end{array}\right]
$$

$\mathrm{PE}$ due to gravity can be given as $G_{j}=$ $\int_{0}^{l_{j}} m g\left[\begin{array}{ll}0 & 1\end{array}\right] x_{j} d x_{j}$. The total elastic $\mathrm{KE}$ and the $\mathrm{PE}$ of link are described as

$$
\begin{gathered}
T=\sum_{j=1}^{n_{1}} T_{j}=\frac{1}{2} \dot{Q}^{T}(t) M \dot{Q}(t) \\
P=\sum_{j=1}^{n} P_{j}+\sum_{j=1}^{n} G_{j}=\frac{1}{2} Q^{T}(t) K Q(t)+G(t)
\end{gathered}
$$

The LE with Lagrange function $L=T-P$ is shown as

$$
\frac{d}{d t}\left(\frac{\partial L}{\partial \dot{Q}(t)}\right)-\frac{\partial L}{\partial Q(t)}=F(t)
$$

When KE and PE are known, the Eq. (10) can be rewritten as

$$
M(Q) \ddot{Q}+D \dot{Q}+K Q+G^{*}=F(t)
$$

Vector $Q(t)=\left[\begin{array}{llllll}d(t) & u_{1} & u_{2} & \ldots & u_{2 n+1} & u_{2 n+2}\end{array}\right]^{T}$ is generalized coordinate overall system. Vector $F(t)=$ $\left[\begin{array}{llllll}F_{t}(t) & 0 & \ldots & 0 & F_{y} & 0\end{array}\right]^{T}$ is the external generalized force. The matrices $M$ and $\mathrm{K}$ are established from matrices $M_{j}$ and $K_{j}$. Vector $G^{*}=\frac{\partial G}{\partial Q(t)}$ can be determined by partial derivative $G(t)=\sum_{j=1}^{n} G_{j}$.Structural damping matrix $D=\alpha M+\beta K$ is calculated as in Ge et al. (1997) ${ }^{12}$. Symbols $\alpha$ and $\beta$ are the damping ratios of the system which are determined by experience. The size of $M, K$ and $D$ matrices is $(2 n \times 3) \times(2 n+3)$. 


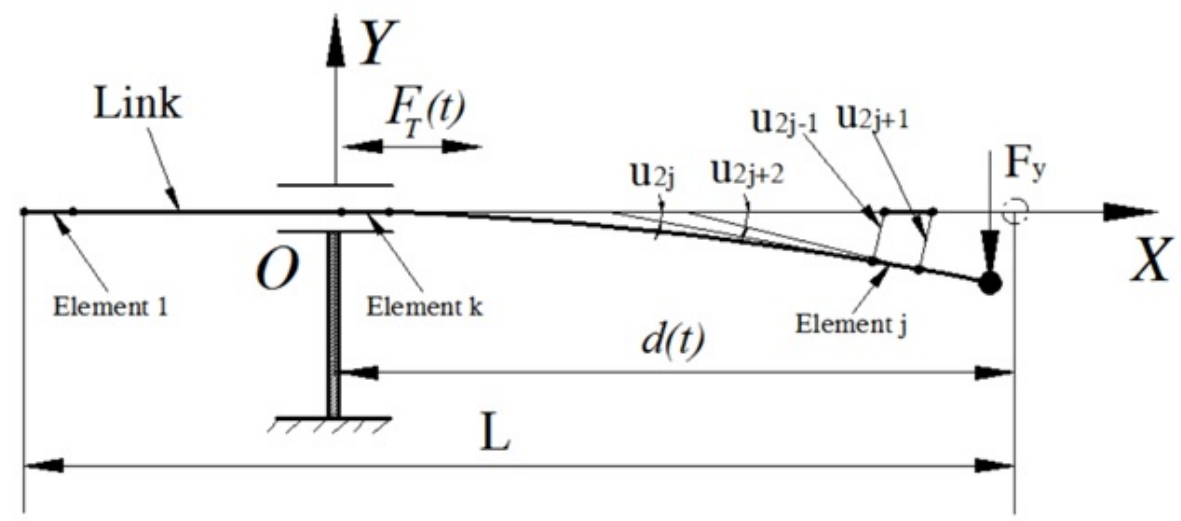

Figure 1: FLR with T joint

\section{BOUNDARY CONDITIONS}

The displacements of element $k$ are zero because assumed that the translational joint hub is treated as rigid. The rows and columns $(2 k-1)^{t h} ;(2 k)^{t h}$ of matrices $M, K, D, G^{*}$ and $F(t), Q(t)$ vectors are eliminated following FEM theory and values of these are continually changed depending on time because of changing of element $k$ position. It is noteworthy to mention that value of $k$ depends on time. This boundary condition is clearly different point between FLR with only $\mathrm{R}$ joints and FLR with combine $\mathrm{T}$ joint and $\mathrm{R}$ joint. So now, size of matrices $M, K, D, G^{*}$ is $(2 n+1) \times(2 n+1)$ and size of $F(t)$ and $Q(t)$ is $(2 n+1) \times 1$. The $k$ variable is continuously updated for each time step in solving process. Vector generalized coordinate $Q(t)$ is rebuilt after each loop too because of changing value $k$ variable (Figure 2).

\section{SYSTEM CONTROL}

In this paper, a PID controller is constructed to control the position of an FLR. The position error of EP of the elastic stitch is continuously reflected and minimized. GA is applied to find the optimal parameters of the PID control system. The error values are used to assess the fitness of each chromosome in the GA. There are some main steps in this algorithm as selection, mutation, crossover, and reproduction. The reproduction step is stopped when an optimum solution is found ${ }^{13}$. The sequences of operations involved in GA are described in Figure 3.

Structural control of dynamic system is designed as Figure 4.
From Figure 4, the objective is to tune the PID parameters with minimum consumable energy and minimum errors which are translational joint variable error $\left(e_{1}=d \_r e f-d \_r e a l\right)$, flexural displacement $u_{2 n}$ as $e_{2}$ and slope displacement $u_{2 n+1}$ as $e_{3}$ of the EP of the FLR. Symbol $u_{\text {pid }}=K_{p} e_{1}+K_{I} \int_{0}^{T_{d}} e_{1} d t+K_{D} \frac{d e_{1}}{d t}$ is the driving force and parameters $K_{P}, K_{I}, K_{D}$ are proportional gain, integral, derivative times, respectively. Definition vectors $e=\left[\begin{array}{lll}e_{1} & e_{2} & e_{3}\end{array}\right]$ and $u=\left[\begin{array}{lll}u_{\text {pid }} & 0 & 0\end{array}\right]$ with time control and the objective function $J$ used in GA is defined as

$$
J=\int_{0}^{T_{d}}\left(e^{T} e+u^{T} u\right) d t
$$

Cost function $J$ is the linear quadratic regulator (LQR $)^{14}$. The optimum target is finding the minimum cost of $J$ function with values of respective parameters which are changed from lower bound to upper bound values. It means to reduce minimum driving energy of joint, error of $\mathrm{T}$ joint variable and elastic displacements at the end-effector point. The optimum parameters $K_{P}, K_{I}, K_{D}$ are given when minimum value of $J$ is found.

\section{SIMULATION RESULT AND DISCUSSIONS}

Parameters of the FLR are shown in Table 1.

It is noteworthy to mention that system has an elastic displacement value at initial time as static state. This initial displacement value is $w_{(t=0)}(0)=\frac{F_{y} \cdot d_{0}^{3}}{3 . E . I}$.

Parameters are used in GA following Table 2.

The reference point and optimum parameters are shown in Table 3.

The cost values of $\mathrm{J}$ function are described in Figure 5. The minimum cost value is 0.0594 . This value shows 


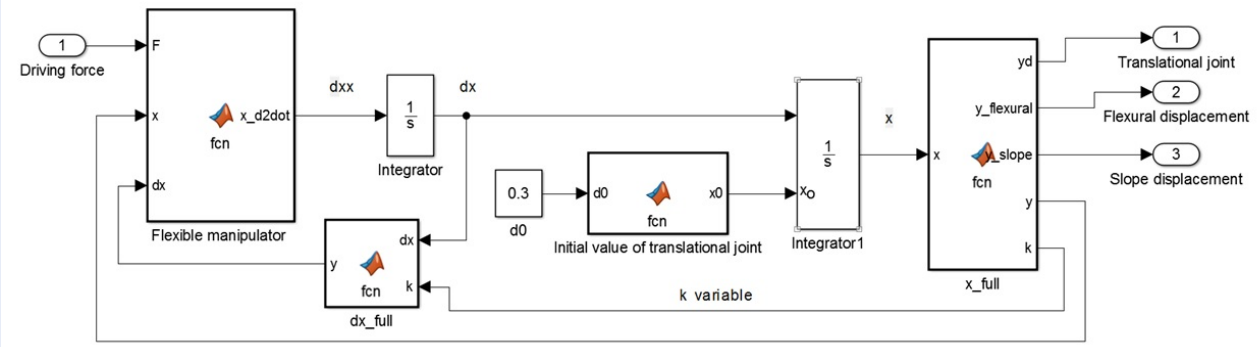

Figure 2: The dynamic model block diagram in SIMULINK

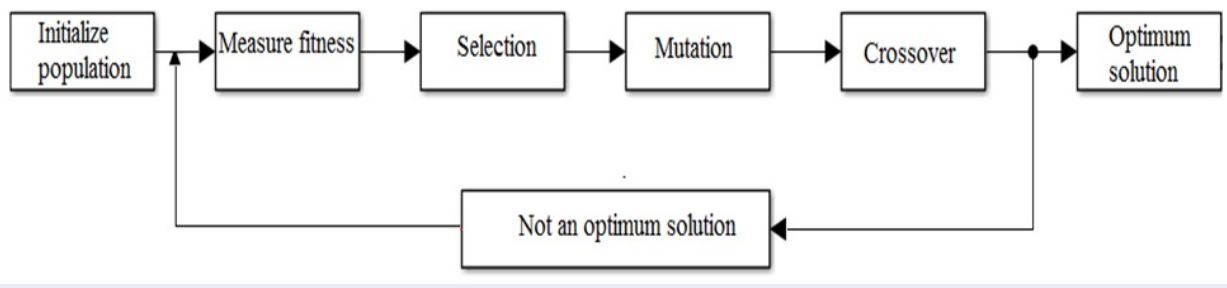

Figure 3: Steps in GAs

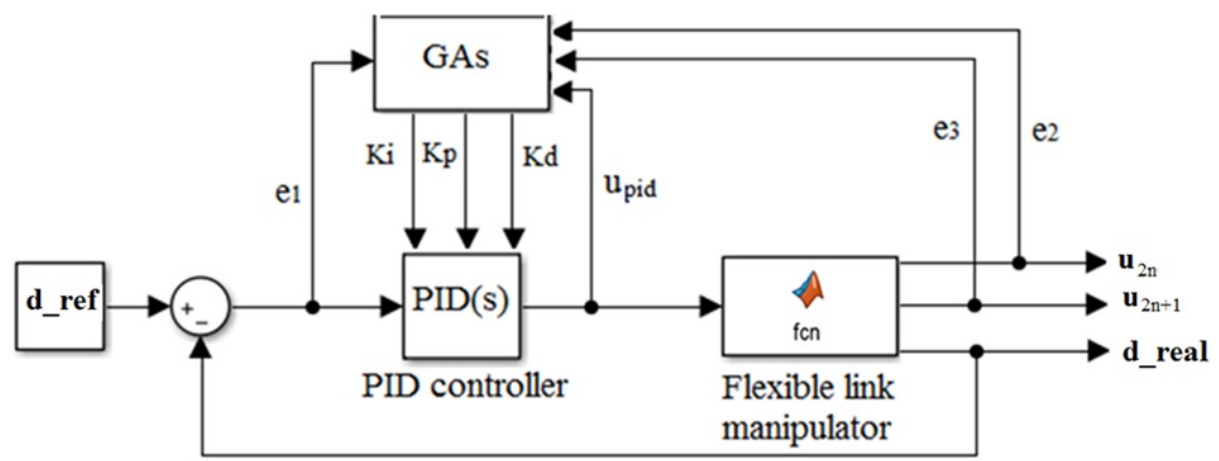

Figure 4: Structure of PID controller

that the control quality is effective. The generation can be reduced.

The simulation results of $\mathrm{T}$ joint, error of joint is shown in Figure 6 and Figure 7. The remaining figures are simulation results of their velocity. Considering $\mathrm{T}$ joint value, rise time is $0.4(\mathrm{~s})$. Settling time is $1.1(\mathrm{~s})$, maximum overshoot is $1.5(\%)$, state error is zero. The velocity of $\mathrm{T}$ joint variable is shown in Figure 8 . The maximum velocity of joint is $1.35(\mathrm{~m} / \mathrm{s})$ and fast reduces after that about 0.8 (s).
The ED values at the EP are fast reduced and show in Figure 9 and Figure 10.

Maximum flexural displacement is $3.8(\mathrm{~mm})$. This value reduced to displacement value at static state after $1.4(\mathrm{~s})$. The maximum slope displacement is 0.175 (rad). It reduced to displacement value at static state after 1.4 (s) too. The velocities of ED are shown in Figure 11 and Figure 12. 


\begin{tabular}{lll} 
Table 1: FLR parameters & & \\
\hline Property & Symbol & Value \\
Length of link $(\mathrm{m})$ & $\mathrm{L}$ & 0.8 \\
Width $(\mathrm{m})$ & $\mathrm{b}$ & 0.005 \\
Thickness $(\mathrm{m})$ & $\mathrm{h}$ & 0.005 \\
Number of elements & $\mathrm{n}$ & 20 \\
Cross section area $\left(\mathrm{m}^{2}\right)$ & $\mathrm{A}=\mathrm{b} \cdot \mathrm{h}$ & $2.5 .10^{-7}$ \\
Mass density $\left(\mathrm{kg} / \mathrm{m}^{3}\right)$ & $\rho$ & 7850 \\
Mass per meter $(\mathrm{kg} / \mathrm{m})$ & $\mathrm{m}=\rho . \mathrm{A}$ & 0.19625 \\
Young's modulus $\left(\mathrm{N} / \mathrm{m}^{2}\right)$ & $\mathrm{E}$ & $2.10^{10}$ \\
Inertial moment of cross section $\left(\mathrm{m}^{4}\right)$ & $\mathrm{I}=\mathrm{b} \cdot \mathrm{h}^{3} / 12$ & $5.208 \times 10^{-11}$ \\
Damping ratios & $\alpha=\beta$ & 0.005 \\
External force $(\mathrm{N})$ & $\mathrm{Fy}$ & 2 \\
Time simulation $(\mathrm{s})$ & $\mathrm{T}$ & 2 \\
\hline
\end{tabular}

Table 3: Simulation data and results

\begin{tabular}{ll}
\hline Property & Value \\
Reference position $(\mathrm{m})$ & 0.7 \\
Initial position $(\mathrm{m})$ & 0.3 \\
Simulation time $(\mathrm{s})$ & 2 \\
Optimum values $\left(\mathrm{K}_{p}, \mathrm{~K}_{i}, \mathrm{~K}_{d}\right)$ & $10.1 ; 0.2 ; 2.5$ \\
The minimum cost value of J function & 0.0594 \\
\hline
\end{tabular}

Table 2: GA parameters

\begin{tabular}{ll}
\hline Property & Value \\
Maximum generation & 50 \\
Population size & 50 \\
Mutation rate & 0.05 \\
Fraction of population kept & 0.5 \\
Number of optimization variables & 3 \\
Lower bound of variables & 0 \\
Upper bound of variables & 30 \\
\hline
\end{tabular}

\section{CONCLUSION}

A dynamic model of a single FLR with T joint is considered based on FEM and LE approach. Considering joint variable which is distance from element $\mathrm{k}$ at the origin coordinate system to the EP of link is effective. The difference between flexible manipulators which have only $\mathrm{R}$ joint and others with $\mathrm{T}$ joint is presented through boundary conditions. Control system is pro-

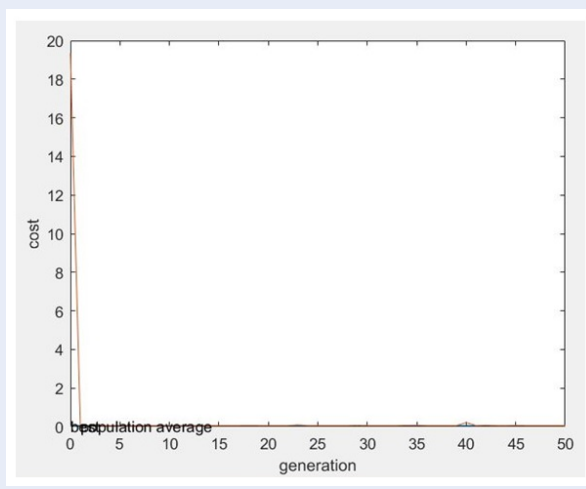

Figure 5: The cost value of J function

posed to reduce elastic displacement value at the EP of link and joint error. Parameters of PID control are optimized by using GA. The output search results are successfully applied to control position. The approach method and results of this study can be referenced to research other flexible robot with more joint or other 


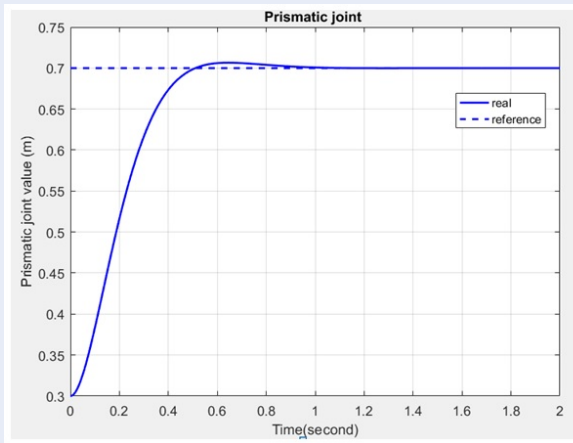

Figure 6: Position control results of $\mathrm{T}$ joint variable

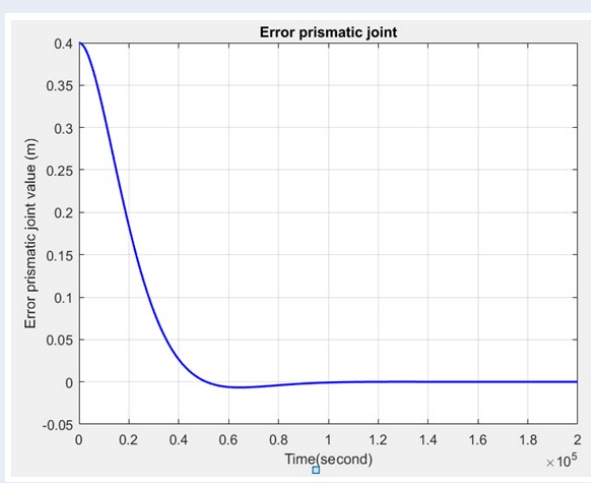

Figure 7: The error of $\mathrm{T}$ joint variable

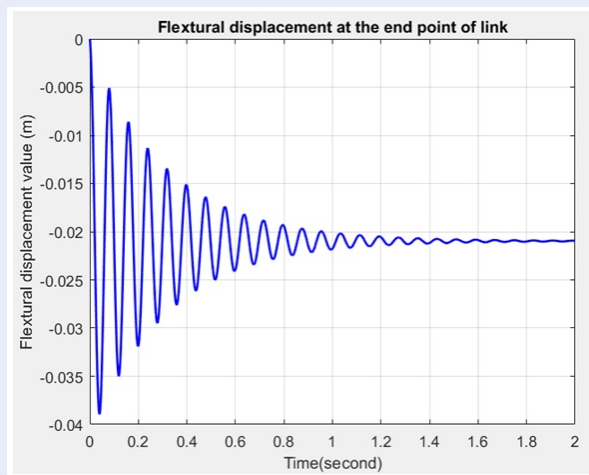

Figure 9: Value of flexural displacement at the EP

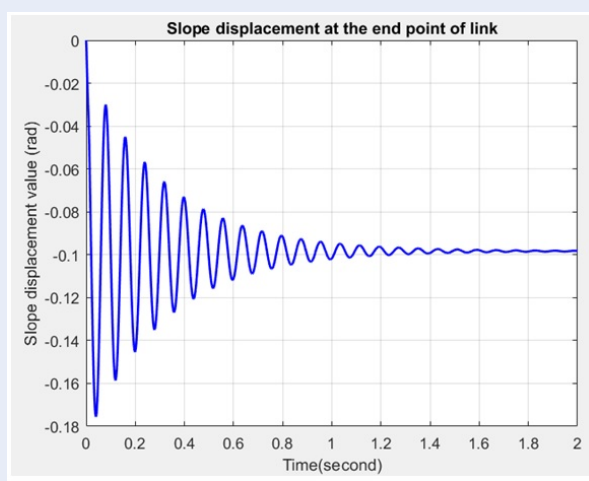

Figure 10: Value of slope displacement at the EP

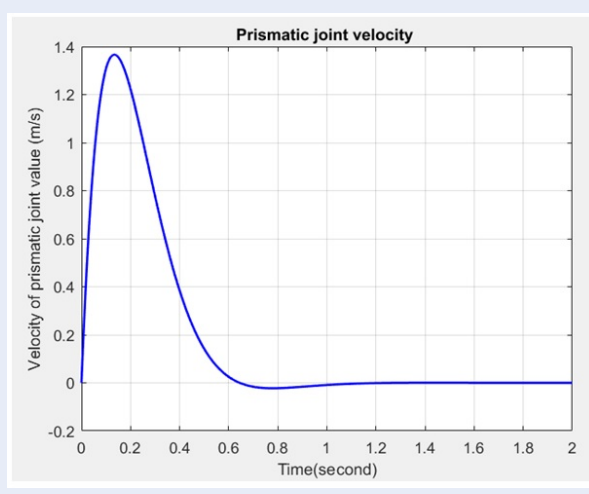

Figure 8: Value of velocity of $\mathrm{T}$ joint

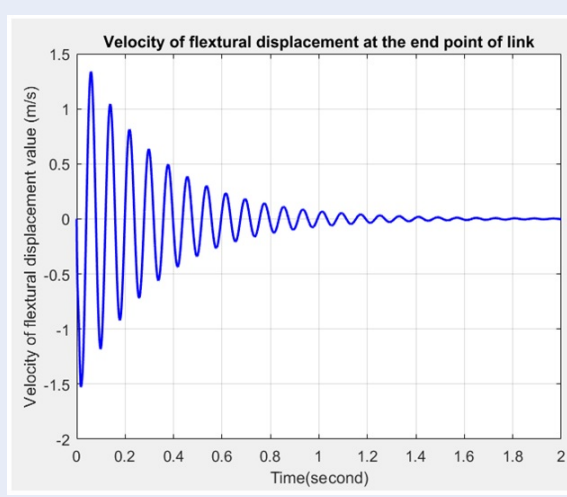

Figure 11: Value of flexural displacement velocity 


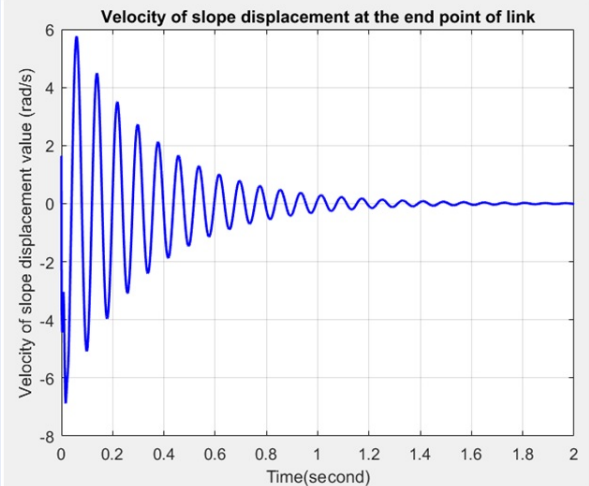

Figure 12: Value of slope displacement velocity

joint styles.

\section{ACKNOWLEDGMENT}

I am extremely grateful to anonymous reviewers for valuable comments that helped to improve this article.

\section{CONFLICT OF INTEREST}

There are no potential conflicts of interest with respect to the research, authorship, and publication of this article.

\section{AUTHOR CONTRIBUTION}

The author is the only person who made the presented study, conducted the numerical simulation, wrote the manuscript, as well as formulated the statement to the problem.

\section{REFERENCES}

1. Wang PKC, Wei JD. Vibration in a moving flexible robot arm Journal of Sound and vibration. 1987;116(1):149-160. Available from: https://doi.org/10.1016/S0022-460X(87)81326-3.

2. Wang PKC, Wei JD. Feedback control of vibrations in a moving flexible robot arm with rotary and translational joints. Pro- ceedings of the IEEE International Conference on Robotics and Automation, Raleigh, North Carolina. 1987;p. 1683-1689.

3. Kwon DS, Book WJ. A time-domain inverse dynamic tracking control of a single link flexible manipulator. Journal of Dynamic Systems, Measurement and Control. 1994;116:193200. Available from: https://doi.org/10.1115/1.2899210.

4. Devasia S, Chen D, Paden B. Non-linear inversion-based output tracking. IEEE Transactions on Automatic Control. 1996;41(7). Available from: https://doi.org/10.1109/9.508898.

5. Eliodoro C, Serna MA. Inverse dynamics of flexible robots. Mathematics and computers in simulation. 1996;41:485-508. Available from: https://doi.org/10.1016/0378-4754(95)00095$\mathrm{X}$.

6. Pan YC, et al. Dynamic modeling and simulation of flexible robots with translational joints. J. Mech. Design. 1990;112:307-314. Available from: https://doi.org/10.1115/1. 2912609.

7. Yuh J, Young T. Dynamic modeling of an axially moving beam in rotation: simulation and experiment. Trans. ASME J. Dyn. Syst. Meas. Control. 1994;113:34-40. Available from: https:// doi.org/10.1115/1.2896355.

8. Al-Bedoor BO, Khulief YA. General planar dynamics of a sliding flexible link", Sound and Vibration. 1997;206(5):641-661. Available from: https://doi.org/10.1006/jsvi.1997.1129.

9. Farid M, Salimi I. Inverse dynamics of a planar flexible-link manipulator with revolute-prismatic joints. American Society of Mechanical Engineers, Design Engineering Division DE. 2001;111:345-350.

10. Qiu ZC. Adaptive nonlinear vibration control of a Cartesian flexible manipulator driven by a ball-screw mechanism. Mechanical Systems and Signal Processing. 2012;30:248-266. Available from: https://doi.org/10.1016/j.ymssp.2012.01.002.

11. Zhao L, Hu ZD. Active Vibration Control of an Axially Translating Robot Arm with Rotating-Translational Joint Using SelfSensing Actuator", Shock and Vibration;2015. Available from: https://doi.org/10.1155/2015/964139.

12. Ge SS, Lee TH, Zhu G. A Nonlinear feedback controller for a single link flexible manipulator based on a finite element method. Journal of robotics system. 1997;14(3):165178. Available from: https://doi.org/10.1002/(SICI)10974563(199703) 14:3<165::AID-ROB2>3.0.CO;2-P.

13. Shaheed MH, Tokhi MO, et al. Modeling and open-loop control of a single link flexible manipulator with genetic algorithm. Journal of low frequency noise, vibration and active control. 2001;p. 39-55. Available from: https://doi.org/10. $1260 / 0263092011492975$.

14. Deif $\mathrm{S}$, et al. Optimal turning of a PD controller for a single link flexible robot arm using adaptive genetic algorithm. 14th International Conference on Aerospace sciences and aviation technology. 2011;Available from: https://doi.org/10. 21608/asat.2011.23261. 


\section{Phân tích động lực học và điều khiển rô bốt có một khâu đàn hồi với khớp tịnh tiến}

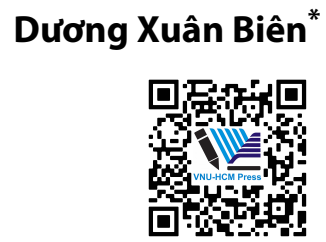

Use your smartphone to scan this QR code and download this article
Trường Đại học Kỹ thuật Lê Quý Đôn, Hà Nội, Việt Nam

\section{Liên hệ}

Dương Xuân Biên, Trường Đại học Kỹ thuật Lê Quý Đôn, Hà Nội, Việt Nam

Email: duongxuanbien@lqdtu.edu.vn

Lịch sử

- Ngày nhận: 14-4-2020

- Ngày chấp nhận: 22-12-2020

- Ngày đăng: 31-12-2020

DOI : 10.32508/stdjet.v3i4.801

\section{Check for updates}

\section{Bản quyền}

๑ ĐHQG Tp.HCM. Đây là bài báo công bố mở được phát hành theo các điều khoản của the Creative Commons Attribution 4.0 International license.

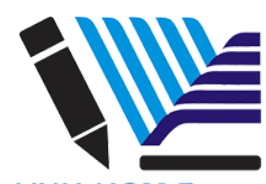

VNU-HCM Press

\section{TÓM TẮT}

Thiết kế hiện đại luôn hướng tới mục tiêu giảm khối lượng, đơn giản hóa cấu trúc và giảm tiêu thụ năng lượng của hệ thống, đặc biệt trong lĩnh vực robot. Các mục tiêu này giúp giảm chi phí vật liệu và nâng cao năng suất hoạt động. Hướng ưu tiên trong thiết kế rô bốt là các cấu trúc tối ưu với chiều dài các khâu dài, nhỏ và mỏng hơn, tiết kiệm vật liệu, giảm khối lượng mà vẫn đảm bảo khả năng làm việc. Tuy nhiên, các thành phần trong kết cấu rô bốt loại này bị giảm độ cứng và độ chính xác chuyển động do ảnh hưởng của yếu tố biến dạng đàn hồi. Do đó, việc xem xét ảnh hưởng của yếu tố đàn hồi là rất cần thiết khi phân tích đông hoc, động lực hoc và điểu khiển. Do tính chất phức tạp của việc mô hình hóa và điêu khiển, rổ bốt đàn hồi có 1 khâu và 2 khâu với chî một loại khớp quay được xem xét và nghiên cứu là chủ yếu trong hầu hết các công trình đã công bố. Dễ nhận ra rằng, việc kết hợp các loại khớp khác nhau cho rô bốt đàn hồi có thể mở rộng các ứng dụng, tính linh hoạt và tính đa dạng về kết cấu của chúng. Tuy nhiên, các rô bốt bao gồm khớp quay và khớp tịnh tiến sẽ làm cho việc phân tích động học, động lực học và điều khiển trở nên phức tạp hơn so với các rô bốt đàn hồi chỉ có khớp quay. Bài báo này trình bày kết quả phân tích động lực học và điều khiển tối ưu vị trí dựa trên thuật toán di truyền (GA) cho rô bốt có một khâu đàn hồi (FLR) với khớp tịnh tiến được giả thiết cứng tuyệt đối. Mô hình động lực học được xầy dựng và phân tích dựa trên phương pháp phần tử hữu hạn. Hệ phương trình mô tả chuyển động được xây dựng từ hể Lagrange. Điểm khác biệt giữa mô hình FLR chỉ với khớp quay và mô hình FLR với khớp tịnh tiến cũng được xem xét dựa trên các điêu kiện biên. Hệ điều khiển PID với các thông số được tìm tối ưu bằng thuật toán GA được thiết kế nhằm giảm tối đa sai lệch biến khớp và sai lệch do chuyển vị đàn hồi (ED) tại điểm thao tác cuối (EP). Kết quả mô phỏng cho thấy, sai lệch biến khớp, giá trị ED đã được triệt tiêu trong thời gian ngắn ứng với yêu cầu ban đầu. Kết quả của bài báo có thể làm nền tảng để tiếp tục nghiên cứu các rô bốt có khâu đàn hồi khác với các loại khớp khác nhau hoặc có sự kết hợp giữa chúng.

Từ khoá: Khâu đàn hồi, khớp tịnh tiến, chuyển vị đàn hồi, điều khiển, thuật toán di truyền
Trích dẫn bài báo này: Biên $D X$. Phân tích động lực học và điều khiển rô bốt có một khâu đàn hồi với khớp tịnh tiến. Sci. Tech. Dev. J. - Eng. Tech.; 3(4):588-595. 